\title{
The Role of Neutral and Radical Anionic Organozinc Complexes in the Alkylation Reactions of 1,4-Diaza-1,3-butadienes with Diorganozinc Compounds'
}

\author{
Evelien Rijnberg, ${ }^{\ddagger}$ J aap Boersma, ${ }^{\ddagger}$ J ohann T. B. H. J astrzebski, ${ }^{\ddagger}$ Miles T. Lakin, ${ }^{\S}$ \\ Anthony L. Spek, §,ll and Gerard van Koten*, \\ Debye Institute, Department of Metal-Mediated Synthesis, and Bijvoet Center for Biomolecular \\ Research, Crystal and Structural Chemistry, Utrecht University, Padualaan 8, \\ $3584 \mathrm{CH}$ Utrecht, The Netherlands
}

Received February $26,1997^{\otimes}$

\begin{abstract}
We have earlier postulated the intermediacy of organozinc radical species in the regiosel ective al kylation reactions of 1,4-di-tert-butyl-1,4-diaza-1,3-butadiene (t-BuNCHCHN$\mathrm{t}-\mathrm{Bu}$ ) with diorganozinc compounds $\left(\mathrm{ZnR} \mathrm{R}_{2}\right)$. To verify these postulates, we have prepared and studied the neutral organozinc radical complex $\mathrm{MeO}\left(\mathrm{CH}_{2}\right)_{3} \mathrm{Zn}(\mathrm{t}-\mathrm{BuNCHCHN}$-t-Bu) (A) and two diorganozinc radical-anionic complexes, $K\left[R_{2} Z n(t-B u N C H C H N-t-B u)\right](R=M e(8 a)$, Et (8b)). A was prepared in situ by the reaction of t-BuNCHCHN-t-Bu with bis(methoxypropyl)zinc. Complexes $\mathbf{8}$ were prepared by reducing the 1:1 coordination complex $\mathrm{ZnMe}_{2}(\mathrm{t}-\mathrm{BuNCHCHN}-\mathrm{t}-\mathrm{Bu}$ ) (1a) with potassium or by the nucleophilic addition of $\mathrm{K}$ (t$\mathrm{BuNCHCHN}$-t-Bu) to $\mathrm{ZnR}_{2}(\mathrm{R}=\mathrm{Me}, \mathrm{Et})$. The resulting radical-anionic complexes are thermally unstable and readily undergo an intermolecular single-electron transfer, giving a mixture of the metallacyclic heteroleptic zincate complexes K[ZnR(t-BuNCHCHN-t-Bu)] (9) and $\mathrm{K}[\mathrm{ZnR}(\mathrm{t}-\mathrm{BuNC}(\mathrm{R}) \mathrm{CHN}-\mathrm{t}-\mathrm{Bu})]$ (10). The ratio in which the latter complexes are formed depends on the $\mathrm{R}$ group and on the concentration and the temperature. Alternatively, 9 has been prepared separately from the reduction of [ $\mathrm{ZnR}(\mathrm{t}-\mathrm{BuNCHCHN}-\mathrm{t}-\mathrm{Bu})]_{2}$ (4) with 2 equiv of potassium. The crystal structures of two complexes of $\mathbf{9}$, i.e. $\{\mathbf{9 a}(\mathbf{T H F})\}_{\mathbf{n}}$ and $\left\{\mathbf{9 c}\left(\mathbf{E t}_{\mathbf{2}} \mathbf{O}\right)_{1 / 2}\right\}_{\mathbf{n}}$, have been determined. Both complexes form linear coordination polymers containing alternating potassium cations and zinc-diazabutadiene anions.
\end{abstract}

\section{Introduction}

It is well-known that 1,4-di-tert-butyl-1,4-diaza-1,3butadiene (t-BuNCHCHN-t-Bu) is alkylated by diorganozinc compounds $\left(\mathrm{ZnR}_{2}\right)$ with high regioselectivity to either the nitrogen-alkylated product $\mathrm{ZnR}(\mathrm{t}-\mathrm{BuN}(\mathrm{R})$ $\mathrm{CHCHN}$-t-Bu) $(\mathrm{R}=$ primary al kyl group) or the carbonalkylated product $\mathrm{ZnR}(\mathrm{t}-\mathrm{BuNCH}(\mathrm{R}) \mathrm{CHN}-\mathrm{t}-\mathrm{Bu})(\mathrm{R}=$ tertiary/benzylic alkyl group). Two possible mechanisms for this alkylation reaction have been put forward, i.e. a radical and a polar mechanism (see Scheme 1). ${ }^{2}$ Earlier studies have shown that the initial step common to both mechanisms is the formation of the thermally unstable $1: 1$ coordination complex $Z_{n R}(t-$ BuNCHCHN-t-Bu) (1), which undergoes an intramolecular single-el ectron-transfer (SET) reaction to give a radical pair, [R・/ZnR(t-BuNCHCHN-t-Bu)*] (2), in a solvent cage. In the radical mechanism $\mathbf{2}$ collapses in

\footnotetext{
* To whom correspondence should be addressed.

† Dedicated to Prof. Dr. Waldemar Adam on the occasion of his 60th birthday.

$\ddagger$ Debye Institute, Department of Metal-Mediated Synthesis.

$\S$ Bijvoet Center for Biomolecular Research, Crystal and Structural Chemistry.

"Address correspondence regarding the crystallography to this author.

${ }^{\otimes}$ Abstract published in Advance ACS Abstracts, J une 15, 1997.

(1) (a) Klerks, J . M.; J astrzebski, J . T. B. H.; van Koten, G.; Vrieze, K. J. Organomet. Chem. 1982, 224, 107. (b) van Koten, G. In Organometallics in Organic Synthesis; de Meijere, A., tom Dieck, H., Eds.; Springer-Verlag: Berlin, 1987; p 277. (c) Kaupp, M.; Stoll, H.; Preuss, H.; Kaim, W.; Stahl, T.; van Koten, G.; Wissing, E.; Smeets, W. J . J .; Spek, A. L. J . Am. Chem. Soc. 1991, 113, 5606.

(2) Wissing, E.; Kaupp, M.; Boersma, J .; Spek, A. L.; van Koten, G. Organometallics 1994, 13, 2349.
}

Scheme 1

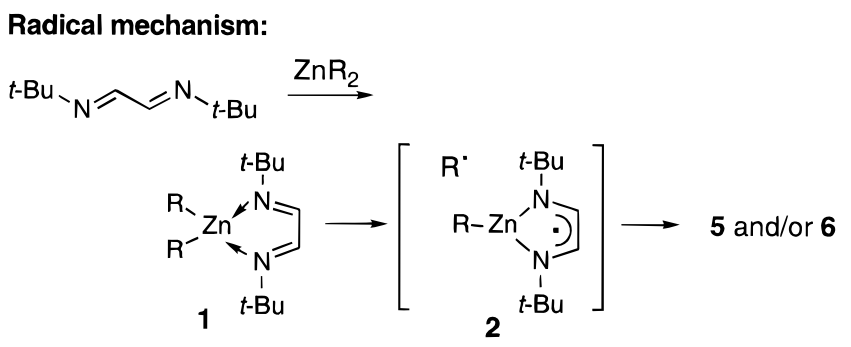

Polar mechanism:

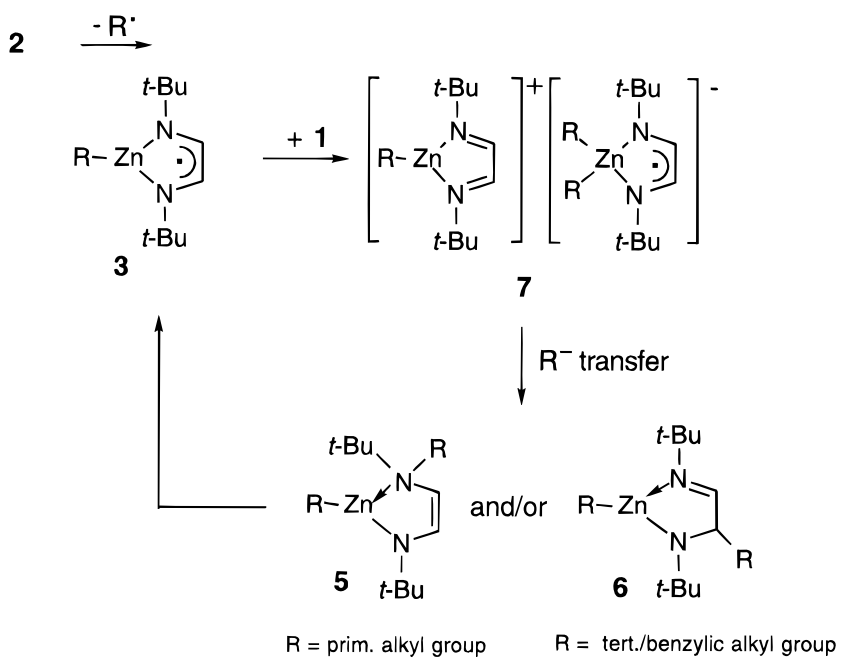

the solvent cage, resulting in the nitrogen- (5) and carbon-alkylated (6) products, whereas in the polar 


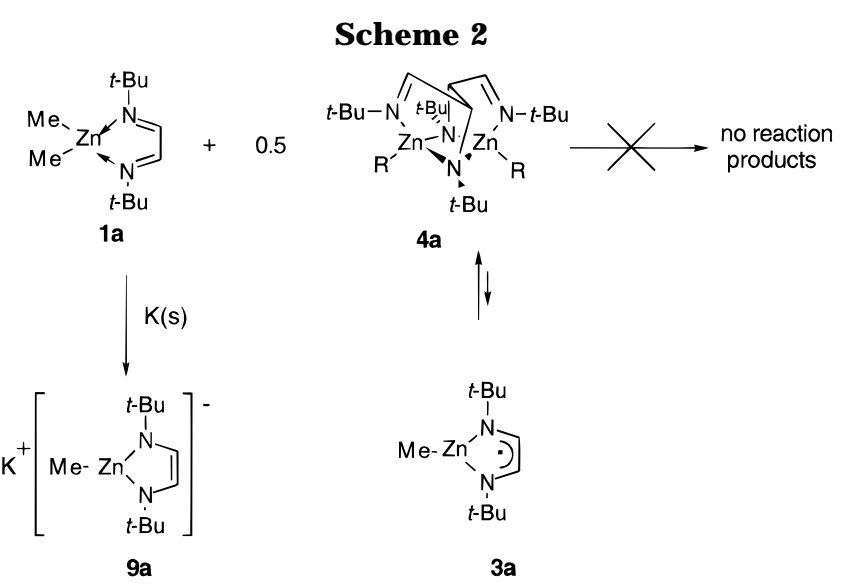

mechanism a steady-state concentration of the free organozinc radical is formed. This transfers its unpaired electron to the initial 1:1 coordination complex $\mathrm{ZnR}_{2}$ (t-BuNCHCHN-t-Bu) (1), to give an organozinc cation/diorganozinc radical-anion pair, [ZnR(t-BuNCH $\mathrm{CHN}-\mathrm{t}-\mathrm{Bu})]\left[\mathrm{ZnR}_{2}\right.$ (t-BuNCHCHN-t-Bu)] (7). Nucleophilic attack of an alkyl group of the diorganozinc radical anion $\left[\mathrm{ZnR}_{2}(\mathrm{t}-\mathrm{BuNCHCHN}-\mathrm{t}-\mathrm{Bu})\right]^{-}$on the organozinc cation [ZnR(t-BuNCHCHN-t-Bu) $]^{+}$gives the alkylation products with simultaneous regeneration of the free organozinc radical (3). In the polar mechanism 5 and 6 can be regarded as 1,2- and 1,4-addition products, respectively.

So far, both mechanisms are supported by the isolation of the 1:1 coordination complex $\mathrm{ZnMe}_{2}(\mathrm{t}-\mathrm{BuNCH}-$ $\mathrm{CHN}-\mathrm{t}-\mathrm{Bu})(\mathbf{1 a})^{1 \mathrm{c}}$ and of $[\mathrm{ZnR}(\mathrm{t}-\mathrm{BuNCHCHN}-\mathrm{t}-\mathrm{Bu})]_{2}(\mathrm{R}$ $=\mathrm{Me}(\mathbf{4 a})$, Et (4b)). The latter exists in solution in equilibrium with the corresponding neutral organozinc radicals [ZnR(t-BuNCHCHN-t-Bu)] $]^{\circ}$ (3) (cf. Scheme 2). ${ }^{1,3}$ Although the radical mechanism has been used as a working hypothesis for the reaction of t-BuNCHCHN$\mathrm{t}-\mathrm{Bu}$ with $\mathrm{ZnR}_{2}$, the proposal of an alternative, polar mechanism is justified by the EPR detection of an unprecedented paramagnetic species during the alkylation reaction in THF. The EPR resonance pattern in THF can only be assigned to a tetrahedrally surrounded organozinc radical complex. 1c In this paper we report the preparation of two different types of complexes having this geometry at zinc, i.e. a model for a solvated neutral organozinc radical and representative examples of diorganozinc radical-anionic complexes. To investigate the role of THF in the formation of the former, we prepared a neutral organozinc radical with a potentially C,O-chelating alkyl group, in which the methoxy substituent may be regarded as a suitably-positioned "solvent" donor molecule. For the preparation of the radical-anionic diorganozinc complexes we have made use of the ability of the t-BuNCHCHN-t-Bu ligand to stabilize electron-rich zinc $\alpha$-di imine complexes, as can be concluded from our recent studies on mono- and dianionic homol eptic zinc complexes. ${ }^{4}$

\section{Results}

Neutral Organozinc Complexes. The EPR spectrum of the reaction mixture of $\mathrm{t}-\mathrm{BuNCHCHN}$-t-Bu with

(3) Wissing, E.; van der Linden, S.; Rijnberg, E.; Boersma, J .; Smeets, W. J . J .; Spek, A. L.; van Koten, G. Organometallics 1994, 13, 2602.

(4) Rijnberg, E.; Richter, B.; Thiele, K.-H.; Veldman, N.; Smeets, W. J . J .; Spek, A. L. van Koten, G. Inorg. Chem., submitted for publication.

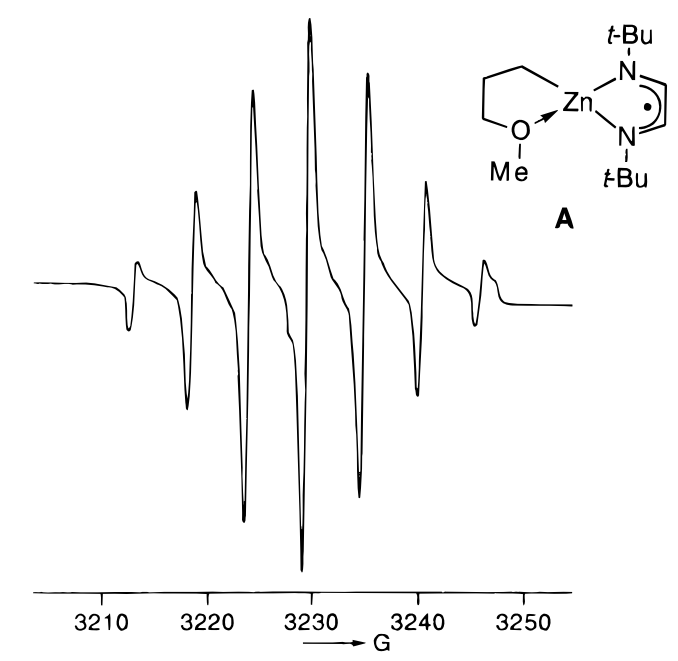

Figure 1. EPR spectrum of the intermediate species (A) in the reaction mixture of t-BuNCHCHN-t-Bu and $\mathrm{Zn}$ $\left(\left(\mathrm{CH}_{2}\right)_{3} \mathrm{OMe}\right)_{2}$ in $\mathrm{Et}_{2} \mathrm{O}(10 \mathrm{G}=1 \mathrm{mT})$.

$\mathrm{Zn}\left[\left(\mathrm{CH}_{2}\right)_{3} \mathrm{OMe}\right]_{2}{ }^{5}$ in $\mathrm{Et}_{2} \mathrm{O}$ at room temperature consists of a resonance pattern of seven broad lines without a hyperfine structure. This is consistent with the presence of an unpaired electron which couples to two magnetically equivalent nitrogen nuclei $(I=1)$ and two magnetically equivalent protons $(I=1 / 2)$ with aH and ${ }^{a} \mathrm{~N}$ coupling constants of 0.49 and $0.59 \mathrm{mT}$, respectively. We assign this spectrum to the C,O-chelate-bonded neutral organozinc radical complex A (see Figure 1).

Radical-Anionic Diorganozinc Complexes. $\mathrm{ZnMe}_{2}$ (t-BuNCHCHN-t-Bu) (1a) is stable at room temperature, in contrast to the corresponding complexes of other $\mathrm{ZnR}_{2}$ compounds. In 1a, homolytic $\mathrm{Zn}-\mathrm{C}$ bond cleavage can only be induced thermally or photochemically. ${ }^{6}$ The stability of $\mathbf{l a}$ enables a more detailed study of its reactivity toward various reducing agents that might be used to prepare radical-anionic diorganozinc complexes. First, the reduction of $\mathbf{l a}$ with the neutral organozinc radical complex [ZnR(t-BuNCHCHN-t-Bu)] (3a) was studied by reacting $\mathbf{l a}$ with 0.5 equiv of the dimer of 3a, i.e. [ZnMe(t-BuNCHCHN-t-Bu) $]_{2}$ (4a), at room temperature (see Scheme 2). We earlier demonstrated that dimeric complexes $\mathbf{4}$ in solution are in equilibrium with two coordinatively unsaturated neutral organozinc radical complexes [ $\mathrm{ZnR}(\mathrm{t}-\mathrm{BuNCHCHN}$ $\mathrm{t}-\mathrm{Bu}$ ) ] ${ }^{\bullet}(\mathbf{3}) .{ }^{1,3}$ The EPR spectrum of a mixture of $\mathbf{1 a}$ and 4a in $\mathrm{Et}_{2} \mathrm{O}$ did show the presence of the unreacted [ZnMe(t-BuNCHCHN-t-Bu)] (3a). ${ }^{\text {Ic }}$ Moreover, the ${ }^{1 \mathrm{H}}$ NMR spectrum of the mixture revealed the presence of the starting materials $\mathbf{1 a}$ and $\mathbf{4 a}$ in a 2:1 molar ratio, while no alkylation products were detected. In contrast to this inertness of $\mathbf{1 a}$ to $\mathbf{3 a}$, the reaction of $\mathbf{1 a}$ with potassium as reducing agent gave, according to the ${ }^{1} \mathrm{H}$ NMR spectrum, the heteroleptic metallacyclic organodiamido zincate anion K[ZnMe(t-BuNCHCHN-t-Bu)] (9a) (see Scheme 2).

9a has also been obtained by two other procedures. First, the reaction of the potassium salt of t-BuNCHCHN$\mathrm{t}-\mathrm{Bu}, \mathrm{K}(\mathrm{t}-\mathrm{BuNCHCHN}-\mathrm{t}-\mathrm{Bu}),{ }^{7}$ with 1 equiv of $\mathrm{ZnMe}_{2}$ gave $9 a$ quantitatively. The application of this proce-

(5) Wissing, E.; Kleijn, H.; Boersma, J .; van Koten, G. Red. Trav. Chim. Pays-Bas 1993, 112, 618.

(6) Wissing, E.; Rijnberg, E.; van der Schaaf, P. A.; van Gorp, K.; Boersma, J .; van Koten, G. Organometallics 1994, 13, 2609.

(7) Clopath, P.; von Zelewsky, A. Helv. Chim. Acta 1972, 55, 52. 
Table 1. Product Ratios in the Reaction of K(t-BuNCHCHN-t-Bu) with $\mathrm{ZnEt}_{2}$

\begin{tabular}{cccc}
\hline $\begin{array}{c}\text { entry } \\
\text { no. }\end{array}$ & $\mathrm{K}(\mathrm{t}-\mathrm{BuNCHCHN}-\mathrm{con}-\mathrm{Bu})(\mathrm{M})$ & $\mathrm{T}(\mathrm{K})$ & $\mathbf{9 b : 1 0 b}$ \\
\hline 1 & 0.15 & 298 & $57: 43$ \\
2 & 0.15 & 195 & $73: 27$ \\
3 & 0.03 & 298 & $77: 23$
\end{tabular}

dure to other $\mathrm{ZnR}_{2}$ compounds ( $\mathrm{R}=\mathrm{Et}, \mathrm{CH}_{2} \mathrm{Ph}$ ) gave a mixture of $\mathrm{K}[\mathrm{ZnR}(\mathrm{t}-\mathrm{BuNCHCHN}-\mathrm{t}-\mathrm{Bu})](\mathrm{R}=\mathrm{Et}(\mathbf{9 b})$, $\left.\mathrm{CH}_{2} \mathrm{Ph}(\mathbf{9 c})\right)$ and $\mathrm{K}[\mathrm{ZnR}(\mathrm{t}-\mathrm{BuNC}(\mathrm{R}) \mathrm{CHN}-\mathrm{t}-\mathrm{Bu})](\mathrm{R}=\mathrm{Et}$ (10b), $\mathrm{CH}_{2} \mathrm{Ph}$ (10c)) (eq 1). According to the mass

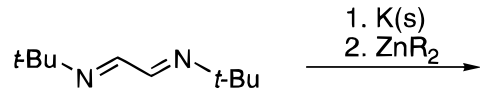

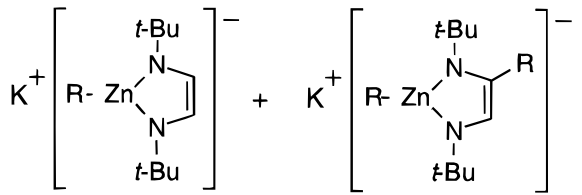

$$
\begin{aligned}
& 9 a \mathrm{R}=\mathrm{Me} \\
& \text { 9b } \mathrm{R}=\mathrm{Et} \\
& \text { 9c } \mathrm{R}=\mathrm{CH}_{2} \mathrm{Ph} \\
& \text { 10b R = Et } \\
& \text { 10c } \mathrm{R}=\mathrm{CH}_{2} \mathrm{Ph}
\end{aligned}
$$

balances the yields of these reactions were $74 \%$ and $99 \%$ with respect to zinc, respectively. No secondary products of organic radicals were observed. We have been unable to separate these zincate complexes. The $\mathbf{9 b}$ : $\mathbf{1 0 b}$ product ratio is dependent on temperature and concentration: at low temperature or at low concentration the formation of $\mathbf{9 b}$ is favored (see Table $\mathbf{1}$ ).

A second route to $9 \mathbf{a}$ is the reaction of $4 \mathbf{a}$ with 2 equiv of potassium. This procedure is also used for the preparation of pure $\mathbf{9 b}$ and $\mathbf{9 c}$ in quantitative yields (eq 2).

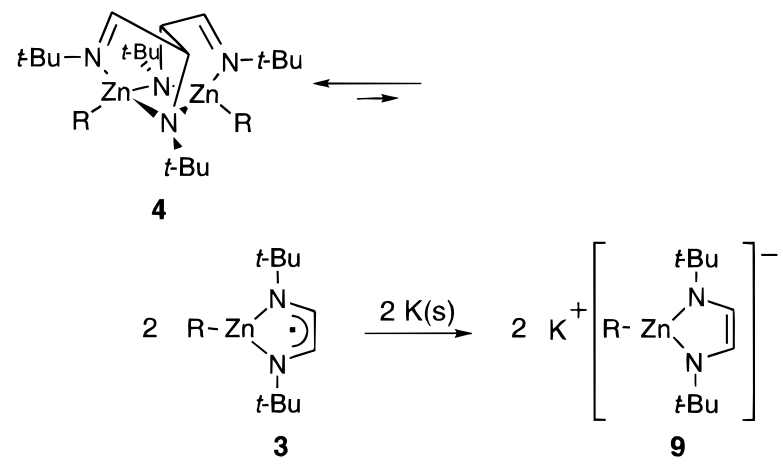

Crystallization of $9 a$ and $9 c$ from $\mathrm{THF} / \mathrm{Et}_{2} \mathrm{O}$ mixtures at $-30{ }^{\circ} \mathrm{C}$ gave crystals of $\{\mathbf{9 a}(\mathbf{T H F})\}_{\mathbf{n}}{ }^{8}$ and $\left\{\mathbf{9 c}\left(\mathbf{E t}_{\mathbf{2}} \mathbf{O}\right)_{\mathbf{1} / 2}\right\}_{\mathbf{n}}$, respectively. The sol id-state mol ecular structures of both complexes consists of linear polymer chains with potassium cations sandwiched between organo(diamido)zincate anions (see Figures 2 and 3). Selected bond lengths and angles for $\{\mathbf{9 a}(\mathbf{T H F})\}_{\mathbf{n}}$ and

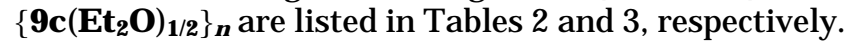
The repeating unit of $\{\mathbf{9 a}(\mathbf{T H F})\}_{\mathbf{n}}$ consists of two [ZnMe(t-BuNCHCHN-t-Bu)] $]^{-}$monoanions, each located on a mirror plane, two [ZnMe(t-BuNCHCHN-t-Bu)] ${ }^{-}$ monoanions, each located on an inversion center, and four bridging potassium cations. The differences in $\mathrm{K}-\mathrm{N}$ and $\mathrm{K}-\mathrm{C}$ distances between two [ $\mathrm{ZnMe}(\mathrm{t}-$ BuNCHCHN-t-Bu)] $]^{-}$units, ranging from 3.023(19) to

(8) Rijnberg, E.; Boersma, J ; J astrzebski, J . T. B. H.; Lakin, M. T. Spek, A. L.; van Koten, G. J . Chem. Soc., Chem. Commun. 1995, 1839.

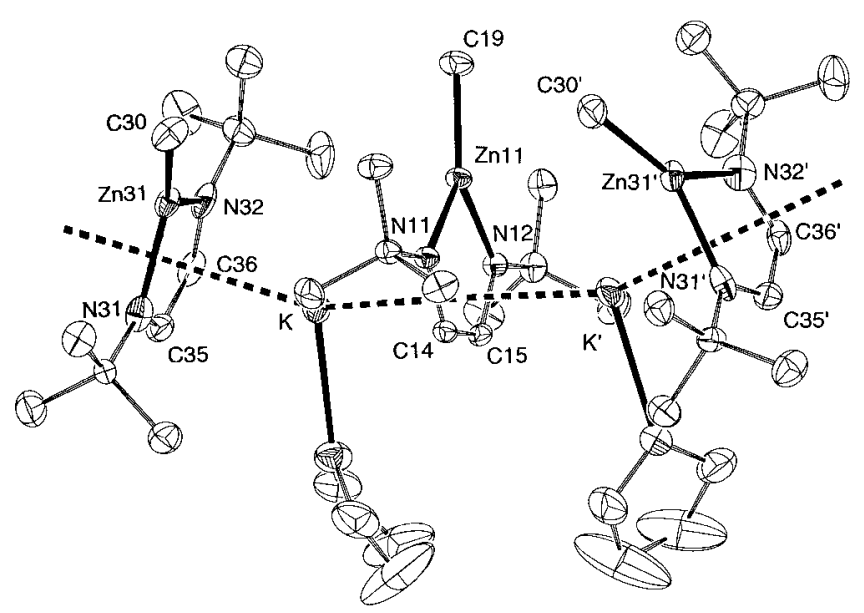

Figure 2. ORTEP drawing at $50 \%$ probability level of the molecular structure of $\{\mathbf{9 a}(\mathbf{T H F})\} \mathbf{n}$. Hydrogen atoms have been omitted for darity.

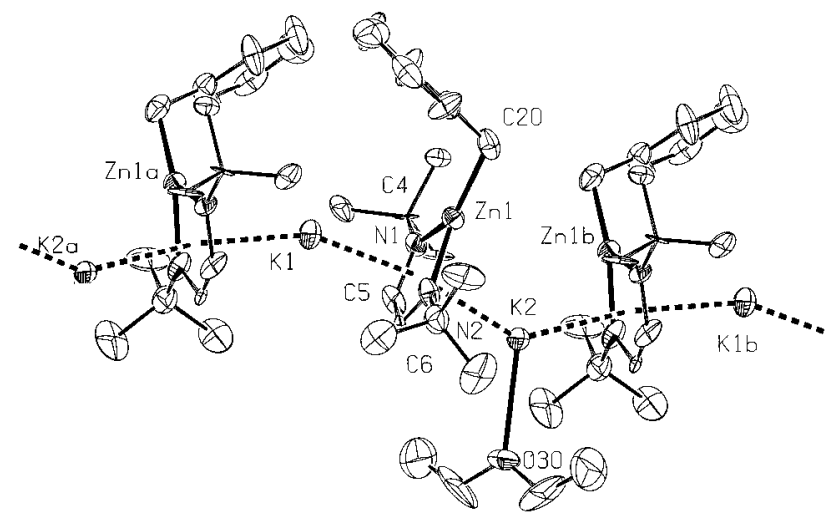

Figure 3. ORTEP drawing at $50 \%$ probability level of the molecular structure of $\left\{\mathbf{9 c}\left(\mathbf{E t}_{\mathbf{2}} \mathbf{O}\right)_{\mathbf{1 / 2}}\right\}_{\mathbf{n}}$. Hydrogen atoms have been omitted for clarity.

Table 2. Selected Bond Lengths and Bond Angles for $\{9 \mathrm{a}(\mathrm{THF})\}_{\mathrm{n}} \mathrm{a}^{\mathrm{a}}$

\begin{tabular}{llll}
\hline & \multicolumn{4}{c}{ Bond Lengths $(\AA)$} \\
$\mathrm{K}-\mathrm{N}(11)$ & $3.1421(16)$ & $\mathrm{K}-\mathrm{N}(31)$ & $3.023(19)$ \\
$\mathrm{K}-\mathrm{N}(12)$ & $3.1895(18)$ & $\mathrm{K}-\mathrm{N}(32)$ & $3.05(2)$ \\
$\mathrm{K}-\mathrm{C}(14)$ & $2.9210(15)$ & $\mathrm{K}-\mathrm{C}(35)$ & $2.986(7)$ \\
$\mathrm{K}-\mathrm{C}(15)$ & $2.9519(16)$ & $\mathrm{K}-\mathrm{C}(36)$ & $3.040(7)$ \\
$\mathrm{Zn}(11)-\mathrm{C}(19)$ & $1.951(5)$ & $\mathrm{Zn}(31)-\mathrm{C}(30)$ & $1.956(7)$ \\
$\mathrm{Zn}(11)-\mathrm{N}(11)$ & $1.956(3)$ & $\mathrm{Zn}(31)-\mathrm{N}(31)$ & $2.03(2)$ \\
$\mathrm{Zn}(11)-\mathrm{N}(12)$ & $1.951(3)$ & $\mathrm{Zn}(31)-\mathrm{N}(32)$ & $2.018(17)$ \\
$\mathrm{N}(11)-\mathrm{C}(14)$ & $1.388(6)$ & $\mathrm{N}(31)-\mathrm{C}(35)$ & $1.291(19)$ \\
$\mathrm{N}(12)-\mathrm{C}(15)$ & $1.391(5)$ & $\mathrm{N}(32)-\mathrm{C}(36)$ & $1.31(2)$ \\
$\mathrm{C}(14)-\mathrm{C}(15)$ & $1.357(6)$ & $\mathrm{C}(35)-\mathrm{C}(36)$ & $1.380(12)$
\end{tabular}

\section{Bond Angles (deg)}

$\mathrm{N}(11)-\mathrm{Zn}(11)-\mathrm{C}(19) \quad 136.81(17) \quad \mathrm{N}(31)-\mathrm{Zn}(31)-\mathrm{C}(30) \quad 139.7(5)$ $\mathrm{N}(12)-Z n(11)-C(19) \quad 138.15(17) \quad \mathrm{N}(32)-Z n(31)-C(30) \quad 138.0(6)$ $\mathrm{N}(11)-\mathrm{Zn}(11)-\mathrm{N}(12) \quad 85.05(14) \quad \mathrm{N}(31)-\mathrm{Zn}(31)-\mathrm{N}(32) \quad 82.0(7)$ $\mathrm{N}(11)-\mathrm{C}(14)-\mathrm{C}(15) \quad 118.2(4) \quad \mathrm{N}(31)-\mathrm{C}(35)-\mathrm{C}(36) \quad 119.7(11)$ $\mathrm{N}(12)-\mathrm{C}(15)-\mathrm{C}(14) \quad 116.8(4) \quad \mathrm{N}(32)-\mathrm{C}(36)-\mathrm{C}(35) \quad 119.0(10)$

a The estimated standard deviations of the last significant digits are shown in parentheses.

3.1895(18) $\AA$ and from $2.9210(15)$ to 3.103(8) $\AA$, respectively, suggest that each potassium cation in the chains is $\eta^{2}+\eta^{4}$ coordinated to the six $\pi$-electrons of the [ZnMe(t-BuNCHCHN-t-Bu)] $]^{-}$units. In addition, one molecule of THF completes the coordination sphere around potassium.

The polymer chain contains two nonequivalent [ZnMe (t-BuNCHCHN-t-Bu) ]- units. The zinc atoms in both have a distorted-trigonal-planar geometry, as illustrated by the sums of the $\mathrm{C}-\mathrm{Zn}-\mathrm{N}$ and $\mathrm{N}-\mathrm{Zn}-\mathrm{N}$ angles 
Table 3. Selected Bond Lengths and Bond Angles for $\left\{9 c\left(E t_{2} O\right)_{1 / 2}\right\} n^{a}$

\begin{tabular}{llll}
\hline \multicolumn{5}{c}{ Bond Lengths $(\AA)$} \\
$\mathrm{K}(1)-\mathrm{N}(1)$ & $2.990(1)$ & $\mathrm{K}(2)-\mathrm{N}(1)$ & $3.171(12)$ \\
$\mathrm{K}(1)-\mathrm{N}(2)$ & $3.081(13)$ & $\mathrm{K}(2)-\mathrm{N}(2)$ & $3.248(14)$ \\
$\mathrm{K}(1)-\mathrm{C}(5)$ & $2.892(15)$ & $\mathrm{K}(2)-\mathrm{C}(5)$ & $2.958(15)$ \\
$\mathrm{K}(1)-\mathrm{C}(6)$ & $2.917(14)$ & $\mathrm{K}(2)-\mathrm{C}(6)$ & $3.034(14)$ \\
$\mathrm{Zn}(1)-\mathrm{C}(20)$ & $1.974(17)$ & $\mathrm{K}(2)-\mathrm{O}(30)$ & $2.777(16)$ \\
$\mathrm{Zn}(1)-\mathrm{N}(1)$ & $1.943(11)$ & $\mathrm{N}(1)-\mathrm{C}(5)$ & $1.393(19)$ \\
$\mathrm{Zn}(1)-\mathrm{N}(2)$ & $1.944(13)$ & $\mathrm{N}(2)-\mathrm{C}(6)$ & $1.360(19)$ \\
$\mathrm{C}(5)-\mathrm{C}(6)$ & $1.36(2)$ & & \\
\multicolumn{5}{c}{} \\
$\mathrm{N}(1)-\mathrm{Zn}(1)-\mathrm{C}(20)$ & \multicolumn{3}{c}{ Bond Angles (deg) } \\
$\mathrm{N}(2)-\mathrm{Zn}(1)-\mathrm{C}(20)$ & $138.6(6)$ & $\mathrm{N}(1)-\mathrm{C}(5)-\mathrm{C}(6)$ & $114.4(14)$ \\
$\mathrm{N}(1)-\mathrm{Zn}(1)-\mathrm{N}(2)$ & $85.5(5)$ & $\mathrm{C}(6)-\mathrm{C}(5)$ & $117.9(13)$
\end{tabular}

a The estimated standard deviations of the last significant digits are shown in parentheses.

(360.01 and $357.77^{\circ}$, respectively), cl ose to the expected $360^{\circ}$. Clear differences are observed in the $\mathrm{Zn}-\mathrm{N}, \mathrm{N}-\mathrm{C}$, and $\mathrm{C}-\mathrm{C}$ bond distances of both units. The $\mathrm{Zn}-\mathrm{N}$ and $\mathrm{C}-\mathrm{C}$ bond distances in the $\mathrm{Zn}(11) \mathrm{NCCN}$ chelate ring are significantly shorter than those found in the $\mathrm{Zn}$ (31)NCCN ring. A comparison of the $\mathrm{Zn}-\mathrm{N}, \mathrm{N}-\mathrm{C}$, and $\mathrm{C}-\mathrm{C}$ bond distances with those found in $\mathrm{K}(\mathrm{thf})_{3}[\mathrm{Zn}(\mathrm{t}-$ BuNCHCHN-t-Bu $\left.)_{2}\right]^{4}$ suggests a dianionic enamide character for the t-BuNCHCHN-t-Bu ligand in $\mathrm{Zn}(11)$ NCCN. The distances found in Zn(31)NCCN are comparable to those found in the radical-anion $\mathrm{t}$ BuNCHCHN-t-Bu ligands in Zn(t-BuNCHCHN-t-Bu) ${ }_{2}{ }^{9}$ and $\mathrm{K}(\mathrm{thf})_{3}\left[\mathrm{Zn}(\mathrm{t}-\mathrm{BuNCHCHN}-\mathrm{t}-\mathrm{Bu})_{2}\right]^{4}{ }^{4}$

The crystallographic repeating unit in $\left\{\mathbf{9 c}\left(\mathbf{E t}_{\mathbf{2}} \mathbf{O}\right)_{\left.\mathbf{1}_{\mathbf{2}}\right\}_{\mathbf{n}}}\right.$ consists of two equivalent $\left[\mathrm{Zn}\left(\mathrm{CH}_{2} \mathrm{Ph}\right)(\mathrm{t}-\mathrm{BuNCHCHN}-\right.$ $\mathrm{t}-\mathrm{Bu})]^{-}$monoanions and two nonequivalent potassium cations, each on a crystallographic 2-fold axis. The nonequivalency of the potassium cations is a result of the nonsymmetrical $\eta^{3}+\eta^{4}$ coordination of the ZnNCCN chelate ring to two potassium cations. $\mathrm{K}(1)$ is twice $\eta^{4}$ coordinated via interactions with the $\mathrm{N}(1), \mathrm{N}(2), \mathrm{C}(5)$, and $\mathrm{C}(6)$ atoms of two $\left[\mathrm{Zn}\left(\mathrm{CH}_{2} \mathrm{Ph}\right)(\mathrm{t}-\mathrm{BuNCHCHN}\right.$-t$\mathrm{Bu})]^{-}$units, while $\mathrm{K}(2)$ is twice $\eta^{3}$-coordinated via interactions with the $N(1), C(5)$, and $C(6)$ atoms of these units. $\mathrm{K}(1)$ is also coordinated to a molecule of $\mathrm{Et}_{2} \mathrm{O}$ to complete its coordination sphere.

The ${ }^{1} \mathrm{H}$ NMR spectra of 9 show a characteristic singlet resonance in the olefinic region and a singlet for two identical t-Bu groups, comparable to the resonances found in, e.g., $\mathrm{Li}_{2}(\mathrm{t}-\mathrm{BuNCHCHN}-\mathrm{t}-\mathrm{Bu})$, ${ }^{10 a} \mathrm{M}(\mathrm{t}-\mathrm{BuNCH}-$ $\mathrm{CHN}-\mathrm{t}-\mathrm{Bu})\left(\mathrm{M}=\mathrm{Si}^{\prime l l}, \mathrm{Ge}^{\mathrm{ll}}\right)_{1}, 10 \mathrm{~b}, \mathrm{c}$ and $\mathrm{K}_{2}$ (thf) $)_{2}[\mathrm{Zn}(\mathrm{t}-$ BuNCHCHN-t-Bu $\left.)_{2}\right]^{4}$ The ${ }^{1} \mathrm{H}$ NMR spectra of the alkylated zincate complexes $\mathbf{1 0}$ show the same characteristic singlet resonance in the ol efinic region as was found for 9, a signal for the alkyl group attached to the olefinic bond, and two singlets for the chemically nonequivalent $\mathrm{t}-\mathrm{Bu}$ groups. The chemical shifts observed for the $\alpha$-protons of the zinc-bonded alkyl groups in $\mathbf{9}$ and $\mathbf{1 0}$ are at higher field relative to those in related neutral organozinc complexes. In comparison with the starting dimeric organozinc complexes $\mathbf{4}$ an upfield shift of $0.57-0.81 \mathrm{ppm}$ is observed for the $\alpha$-protons of the

(9) Gardiner, M. G.; Hanson, G. R.; Henderson, M. J .; Lee, F. C.; Raston, C. Inorg. Chem. 1994, 33, 2456.

(10) (a) Görls, H.; Neumüller, B.; Scholtz, A.; Scholtz, J . Angew. Chem., Int. Ed. Engl. 1995, 34, 673. (b) Denk, M.; Lennon, R.; Hayashi, R.; West, R.; Belyakov, A. V.; Verne, H. P.; Haaland, A.; Wagner, M.; Metzler, N. J. Am. Chem. Soc. 1994, 116, 2691. (c) Herrmann, W. A.; Denk, M.; Behm, J .; Scherer, W.; Klingan, F.; Bock, H.; Solouki, B.; Wagner, M. Angew. Chem., Int. Ed. Engl. 1992, 31, 1485. zinc-bound alkyl groups, probably due to the enhanced negative charges on the alkyl groups in the zincate complexes 9 and $\mathbf{1 0}$.

The EPR spectra of the reaction mixture of $\mathrm{K}$ (tBuNCHCHN-t-Bu) and $\mathrm{ZnR}_{2}(\mathrm{R}=\mathrm{Me}, \mathrm{Et})$ showed the presence of paramagnetic species (a similar reaction with $\mathrm{Zn}\left(\mathrm{CH}_{2} \mathrm{Ph}\right)_{2}$ was EPR silent). The relatively broad signals hamper the precise determination of the $\mathrm{g}$ values. However, after approximately $30 \mathrm{~min}$ the EPR signals had disappeared completely. Both species show identical resonance patterns, which is consistent with an unpaired electron being coupled to two magnetically equivalent nitrogen nuclei $(I=1)$ and two magnetically equivalent protons $(I=1 / 2)$ with ${ }^{\text {a }} \mathrm{H}$ and a $\mathrm{N}$ coupling constants of 0.45 and $0.64 \mathrm{mT}$, respectively, without hyperfine splitting. Therefore, we assigned these EPR spectra to the radical-anionic diorganozinc complexes $\mathrm{K}\left[\mathrm{ZnR}_{2}(\mathrm{t}-\mathrm{BuNCHCHN}-\mathrm{t}-\mathrm{Bu})\right](\mathrm{R}=\mathrm{Me}(\mathbf{8 a}), \mathrm{Et}(\mathbf{8 b}))$. The EPR spectra of $\mathbf{8}$ are different from that of $\mathrm{K}(\mathrm{t}-$ BuNCHCHN-t-Bu); the latter shows ${ }^{a} \mathrm{H}$ and a ${ }^{\mathrm{N}}$ coupling constants of 0.43 and $0.56 \mathrm{mT}$, respectively. ${ }^{7}$

\section{Discussion}

Neutral Organozinc Radicals. The EPR spectrum of the reaction mixture of t-BuNCHCHN-t-Bu with $\mathrm{Zn}$ $\left[\left(\mathrm{CH}_{2}\right)_{3} \mathrm{OMe}\right]_{2}^{5}$ in $\mathrm{Et}_{2} \mathrm{O}$ shows a resonance pattern of seven broad lines without hyperfine structure. This lack of hyperfine coupling in the EPR spectrum indicates the presence of a species with a tetrahedral geometry at the zinc atom. We believe that this is brought about by intramolecular $\mathrm{O}-\mathrm{Zn}$ coordination to give a $\mathrm{C}, \mathrm{O}$-chelated neutral organozinc radical. The intramolecular coordination of the methoxy substituent in the alkyl group illustrates the Lewis-acidic character of the zinc atom in neutral organozinc radicals and leads to a deformation of the planar geometry around zinc. The formation of such a species was investigated to mimic the postulated formation of the solvated tetracoordinated neutral organozinc radical $[\mathrm{ZnR}(\mathrm{t}-\mathrm{BuNCH}-$ $\mathrm{CHN}-\mathrm{t}-\mathrm{Bu})(\mathrm{THF}) \mathrm{]}^{\bullet}$ in THF solution. The presence of such a solvated neutral organozinc radical species during the alkylation reaction in THF is in agreement with the aforementioned EPR data of the unknown key intermediate ${ }^{2}$ and therefore supports the postulated radical mechanism.

Radical-Anionic Diorganozinc Complexes. The observed stability of $\mathrm{ZnMe}_{2}$ (t-BuNCHCHN-t-Bu) (1a) toward reduction with [ZnMe(t-BuNCHCHN-t-Bu)] (3a) demonstrates that the ionization energy of $6 \mathrm{eV}$ for $\mathbf{3 a}^{11}$ is too high to let it act as a one-electron donor for the reduction of 1a. However, the reduction of 1a with potassium in situ gives radical-anionic $\mathrm{K}\left[\mathrm{ZnMe}_{2}(\mathrm{t}-\right.$ BuNCHCHN-t-Bu)] (8a), which was thermally converted into the diamagnetic zincate species K [ZnMe(tBuNCHCHN-t-Bu)] (9a). Similar reductions of 1:1 diorganozinc coordination complexes of 2,2'-bipyridine and 3,4,7,8-tetramethyl phenanthroline ligands with potassium in situ gave radical-anionic diorganozinc complexes, which have been studied with EPR. ${ }^{12}$ Counting of $\pi$-electrons in $\mathbf{9 a}$ suggested an alternative preparative route involving the reduction of dimeric [ $\mathrm{ZnR}(\mathrm{t}-$

(11) Louwen, J . N.; Stufkens, D. J .; Oskam, A. J . Chem. Soc., Dalton Trans. 1984, 2683. 1992. 


\section{Scheme 3}

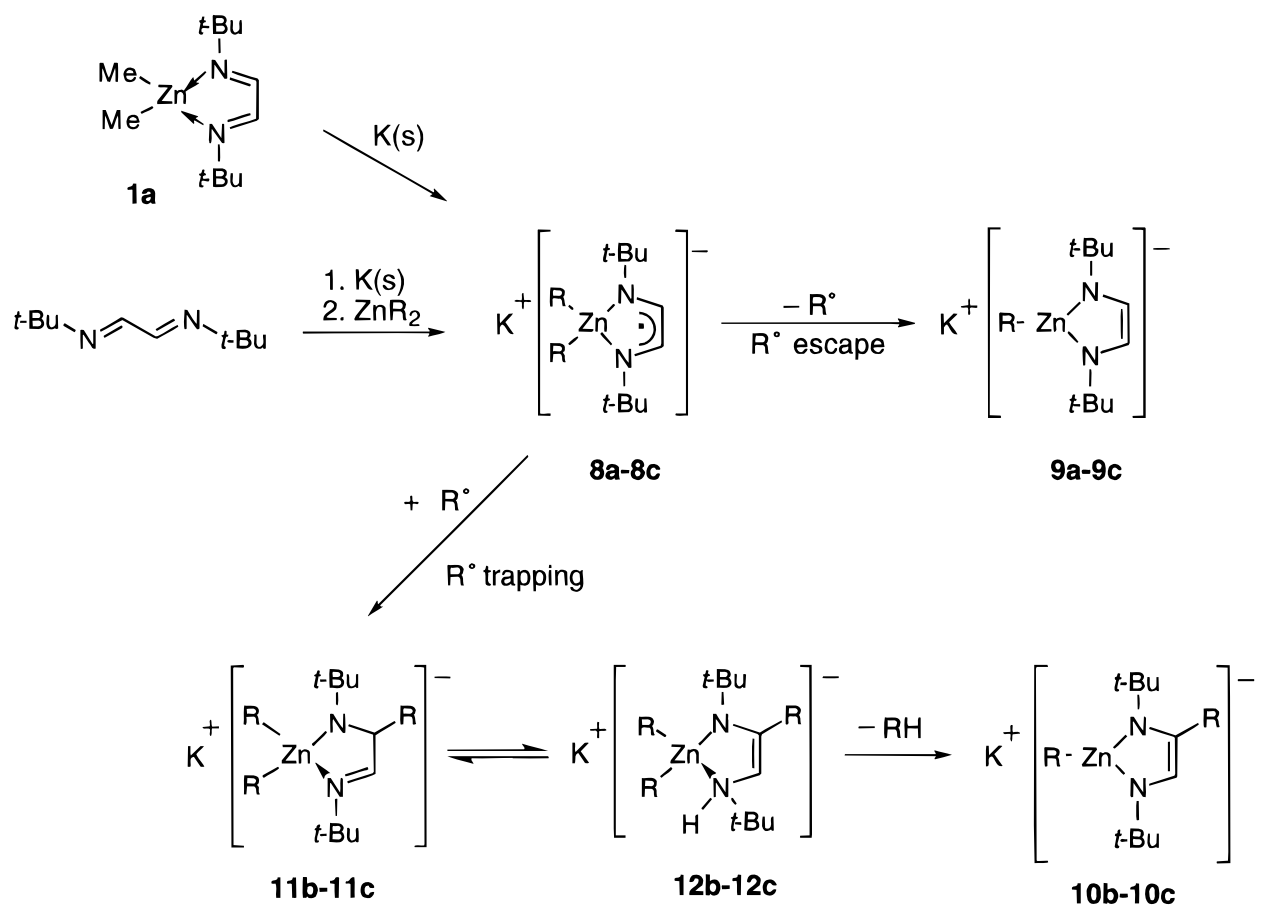

BuNCHCHN-t-Bu) $]_{2}$ with 2 equiv of potassium. Most likely, the neutral organozinc radical is the active species in this reaction. Compound 9a was also prepared by the reaction of $\mathrm{K}(\mathrm{t}-\mathrm{BuNCHCHN}-\mathrm{t}-\mathrm{Bu})$ with $\mathrm{ZnMe}$, while this reaction with $\mathrm{ZnR}_{2}\left(\mathrm{R}=\mathrm{Et}, \mathrm{CH}_{2} \mathrm{Ph}\right)$ gave mixtures of products, from which $\mathrm{K}[\mathrm{ZnR}(\mathrm{t}-\mathrm{BuNCH}$ CHN-t-Bu)] (9) and K[ZnR(t-BuNC(R)CHN-t-Bu)] (10) have been isol ated.

Complexes $\mathbf{9}$ and $\mathbf{1 0}$ are the first examples of heteroleptic organozincate complexes, containing a chelatebonded dianionic diamide ligand. So far, the only known metallacyclic zincate complexes are [ $\mathrm{Li}(\mathrm{L})_{2} \mathrm{Zn}$ $\left(-\mathrm{CHR}(\mathrm{CHR})_{n} \mathrm{CHR}-\right)_{2}\left(\mathrm{~L}=\mathrm{Et}{ }_{2} \mathrm{O} ; 2 \mathrm{~L}=\mathrm{Me}_{2} \mathrm{NCH}_{2} \mathrm{CH}_{2-}\right.$ $\left.\left.\mathrm{NMe}_{2}, \mathrm{MeOCH}_{2} \mathrm{CH}_{2} \mathrm{OMe} ; \mathrm{n}=2,3 ; \mathrm{R}=\mathrm{H}, \mathrm{Me}\right)\right] .{ }^{13}$ Earlier reports on heteroleptic zincates concern the crystal structure of $\left[\mathrm{KZnEt}_{2}(\mathrm{O}-\mathrm{t}-\mathrm{Bu})\right]_{2}$, derived from $\mathrm{ZnEt}_{2}$ and KO-t-Bu, ${ }^{14}$ and the NMR characterization of $\mathrm{LiZnBr} 2\left(\mathrm{C}\left(\mathrm{SiMe}_{3}\right)_{3}\right)$, prepared from $\mathrm{ZnBr}_{2}$ and $\mathrm{LiC}$ $\left(\mathrm{SiMe}_{3}\right)_{3} \cdot{ }^{15}$

A plausible mechanism for the formation of the zincate complexes $\mathbf{9}$ and $\mathbf{1 0}$ is outlined in Scheme 3. Both the nucleophilic addition reaction of $\mathrm{K}(\mathrm{t}-\mathrm{BuNCH}$ $\mathrm{CHN}$-t-Bu) to various $\mathrm{ZnR}_{2}$ compounds and the reduction reaction of $\mathbf{l a}$ with potassium result in the in situ formation of thermally unstable $\mathbf{8}$. When the temperature is raised above its decomposition temperature, $\mathbf{8}$ undergoes a homolytic cleavage of one of the zinccarbon bonds to give an alkyl radical $\left(\mathrm{R}^{\bullet}\right)$ and a biradical organozinc species. Recombination of these two unpaired el ectrons gives, after subsequent rearrangement, the diamagnetic zincate complex $\mathbf{9}$ (the $\mathrm{R} \cdot$-escape product). For $\mathrm{R}=\mathrm{Et}, \mathrm{CH}_{2} \mathrm{Ph}$ these alkyl radicals are partly trapped by collapsing with 8 to give $K\left[\mathrm{ZnR}_{2}(\mathrm{t}-\mathrm{BuNCH}\right.$ -

(13) (a) Fröhlich, H.-O.; Kosan, B.; Müller, B.; Hiller, W. J . Organomet. Chem. 1992, 441, 177. (b) Fröhlich, H.-O.; Kosan, B.; Undeutsch, B.; Görls, H. J . Organomet. Chem. 1994, 472, 1.

(14) Fabicon, R.; Parvez, M.; Richey, H. G., J r. J . Am. Chem. Soc. 1991, 113, 1412.

(15) Westerhausen, M. B.; Rademacher, B.; Schwartz, W.; Weidlein, J .; Henkel, S. J . Organomet. Chem. 1994, 469, 135.
(R)CHN-t-Bu)] (11). Complex $\mathbf{1 1}$ is thought to be in equilibrium with its tautomer, $\mathrm{K}\left[\mathrm{ZnR} \mathrm{R}_{2}(\mathrm{t}-\mathrm{BuNC}(\mathrm{R}) \mathrm{CHN}\right.$ (H)-t-Bu)] (12). A subsequent intramolecular hydrolysis of one of the zinc-carbon bonds by the amino hydrogen in $\mathbf{1 2}$ finally results in the formation of the zincate $\mathbf{1 0}$ (the R・-trapping product).

Similar imino-enamino tautomerization processes have been reported for the carbon-alkylated organozinc compounds $\mathrm{ZnR}(\mathrm{t}-\mathrm{BuNCH}(\mathrm{R}) \mathrm{CHN}-\mathrm{t}-\mathrm{Bu})$, which are in equilibrium with their enamino tautomers $\mathrm{ZnR}$ (t-BuNC$(\mathrm{R}) \mathrm{CHN}(\mathrm{H})-\mathrm{t}-\mathrm{Bu})_{.}^{2,6}$ According to this proposed mechanism for the formation of $\mathbf{9}$ and $\mathbf{1 0}$, the maximum yield of the alkylated zincates $\mathbf{1 0}$ is $50 \%$ with respect to $\mathbf{8}$. Therefore, the formation of $\mathbf{1 0}$ in yiel ds lower than $50 \%$ must be accompanied by a loss of alkyl radicals. Attempts to trap these alkyl radicals as their secondary products have as yet been unsuccessful. The quantitative formation of $9 \mathbf{a}$ without concurrent formation of 10a, from both the nucleophilic addition reaction and the reduction reaction, supports the bimol ecular reaction pathway for the formation of the latter. The homolytic cleavage of a zinc-carbon bond in thermally unstable $8 \mathbf{a}$ gives $\mathbf{9 a}$ and a methyl radical. The latter are highly reactive at room temperature, which results in radical escape from the solvent cage, rather than a collapse with $\mathbf{8 a}$. The favored formation of $\mathbf{9 b}$ with respect to $\mathbf{1 0 b}$ at low temperature and at low concentration also supports the proposed bimolecular process for the formation of $\mathbf{1 0 b}$.

An interesting aspect of the solid-state structures of $\left\{\mathbf{9 a}(\mathbf{T H F})_{\mathbf{n}}\right.$ and $\left\{\mathbf{9 c}\left(\mathbf{E t}_{\mathbf{2}} \mathrm{O}\right)_{\mathbf{1} / \mathbf{2}}\right\}_{\mathbf{n}}$ is that they display three different coordination modes for the monoanionic [ZnR(t-BuNCHCHN-t-Bu)]- units. The significant differences of the $\mathrm{Zn}-\mathrm{N}, \mathrm{N}-\mathrm{C}$, and $\mathrm{C}-\mathrm{C}$ bond distances of the two nonequivalent [ZnMe(t-BuNCHCHN-t-Bu)] units in polymeric $\{\mathbf{9 a}(\mathbf{T H F})\}_{\mathbf{n}}$ are a consequence of the fact that the Zn(11)-containing units act as two-electron donors, while the $\mathrm{Zn}(31)$-containing units act as sixelectron donors. The $\left[\mathrm{Zn}\left(\mathrm{CH}_{2} \mathrm{Ph}\right)(\mathrm{t}-\mathrm{BuNCHCHN}-\mathrm{t}-\mathrm{Bu})\right]^{-}$ 
units in $\left\{\mathbf{9 c}\left(\mathbf{E t}_{\mathbf{2}} \mathbf{O}\right)_{\mathbf{1 / 2}}\right\}_{\mathbf{n}}$ act as four-el ectron donors. The potassium cations in solvent-free $\mathbf{9}$ are most likely twice $\eta^{4}$-coordinated to two [ZnR(t-BuNCHCHN-t-Bu)] $]^{-}$units, both acting as six-electron donors. An increase of the electron-donating properties is accompanied by a shortening of the $\mathrm{C}-\mathrm{N}$ bond distances in the series [ $\mathrm{Zn}(11)$ $\mathrm{Me}(\mathrm{t}-\mathrm{BuNCHCHN}-\mathrm{t}-\mathrm{Bu})]^{-}\left(2 \mathrm{e}^{-}\right)>\left[\mathrm{Zn}\left(\mathrm{CH}_{2} \mathrm{Ph}\right)(\mathrm{t}-\mathrm{BuNCH}-\right.$ $\mathrm{CHN}-\mathrm{t}-\mathrm{Bu})]^{-}\left(4 \mathrm{e}^{-}\right)>[\mathrm{Zn}(31) \mathrm{Me}(\mathrm{t}-\mathrm{BuNCHCHN}-\mathrm{t}-\mathrm{Bu})]^{-}$ $\left(6 \mathrm{e}^{-}\right)$. The apparent radical-anionic character of the t-BuNCHCHN-t-Bu ligand in the [Zn(31)M e(t-BuNCHCHN-t-Bu) $]^{-}$unit of $\{\mathbf{9 a}(\mathbf{T H F})\}_{\mathbf{n}}$ is caused by a shift of its $\pi$-electron density into the direction of both potassium cations. The ${ }^{1} \mathrm{H}$ NMR spectra of 9 in THF solution show one singlet for the ol efinic protons. This suggests that in THF all [ZnR(t-BuNCHCHN-t-Bu)] ${ }^{-}$units in the polymer act as symmetrical $\eta^{2}$-coordinated two-electron donors or, alternatively, that the polymeric structures are completely dissociated into monomeric ion-separated solvated complexes.

\section{Concluding Remarks}

The results presented in this paper provide indirect evidence for a radical mechanism in the alkylation reactions of t-BuNCHCHN-t-Bu with diorganozinc compounds. The paramagnetic species detected during this alkylation reaction in THF is tentatively assigned to be the solvated neutral organozinc radical complex [ZnR(t-BuNCHCHN-t-Bu)(THF)]: This conclusion is further corroborated by the observed stability of the 1:1 coordination complex $\mathbf{1 a}$ toward reduction by $\mathbf{3 a}$. Nevertheless, we have shown that radical-anionic diorganozinc complexes of t-BuNCHCHN-t-Bu can exist, although they have limited thermal stabilities. Their thermal decomposition gave the corresponding heteroleptic organo(diamido)zincates, al kylated or not alkylated at the carbon atom of the t-BuNCHCHN-t-Bu ligand. The nonalkylated derivatives have been prepared independently via an alternative route. The synthetic potential of these new complexes in organozinc-mediated reactions is the subject of further study.

\section{Experimental Section}

General Data. All experiments were carried out under a dry and oxygen-free nitrogen atmosphere, using standard Schlenk techniques. $\mathrm{Et}_{2} \mathrm{O}$, THF, $\mathrm{C}_{6} \mathrm{H}_{6}$, and pentane were dried and distilled from $\mathrm{Na}$ /benzophenone prior to use. $\mathrm{CH}_{2} \mathrm{Cl}_{2}$ was dried and distilled from $\mathrm{CaH}_{2}$. All standard chemicals were purchased from Aldrich and Janssen Chimica. $\mathrm{ZnMe}_{2}(\mathrm{t}-$ BuNCHCHN-t-Bu) (la), ${ }^{1 \mathrm{C}}[\mathrm{ZnR}(\mathrm{t}-\mathrm{BuNCHCHN}-\mathrm{t}-\mathrm{Bu})]_{2}(\mathrm{R}=\mathrm{Me}$ (4a), Et (4b)), ${ }^{3} \mathrm{ZnCl}_{2},{ }^{16}$ 1,4-di-tert-butyl-1,4-diaza-1,3-butadiene (t-BuNCHCHN-t-Bu), ${ }^{17}$ and $\mathrm{Zn}\left(\mathrm{CH}_{2} \mathrm{Ph}_{2}\right)_{2}{ }^{18}$ were prepared according to literature procedures. ${ }^{1} \mathrm{H}$ and ${ }^{13} \mathrm{C}$ NMR spectra were recorded at 200 and $50 \mathrm{MHz}$ in $\mathrm{C}_{6} \mathrm{D}_{6}, \mathrm{CD}_{2} \mathrm{Cl}_{2}$, or THF- $\mathrm{d}_{8}$ at room temperature using $\mathrm{SiMe}_{4}$ as external standard. Coupling $(\mathrm{J})$ constants are in hertz $(\mathrm{Hz})$. EPR spectra were recorded in $\mathrm{Et}_{2} \mathrm{O}$ or THF at room temperature. Melting points are uncorrected. Elemental analyses were carried out by Dornis und Kol be Mikroanalytisches Laboratorium, Mülheim a.d. Ruhr, Germany.

Reaction of t-BuNCHCHN-t-Bu with $\mathrm{Zn}\left(\mathrm{CH}_{2} \mathrm{CH}_{2} \mathrm{CH}_{2-}\right.$ OMe)2. This reaction was carried out according to the

(16) Hamilton, R. T.; Butler, J . A. V. J . Chem. Soc. 1932, 2283.

(17) Kliegman, J. M.; Barnes, R. K. Tetrahedron 1970, 62, 2555.

(18) Weissig, V.; Beckhaus, R.; Banasiak, U.; Thiele, T. H. Z. Anorg.

Allg. Chem. 1980, 467, 61. procedure described in ref 5 . EPR spectra of this reaction mixture were recorded in $\mathrm{Et}_{2} \mathrm{O}$ at room temperature.

Reduction of $\mathrm{ZnMe}_{2}$ (t-BuNCHCHN-t-Bu) (1a). Method A: With 4a. To a solution of $\mathbf{1 a}$, prepared in situ from t-BuNCHCHN-t-Bu (0.28 g; $1.66 \mathrm{mmol})$ and $\mathrm{ZnMe} 2(1.70 \mathrm{~mL}$ of a $1.0 \mathrm{M}$ solution in hexane, $1.70 \mathrm{mmol}$ ) in $\mathrm{Et}_{2} \mathrm{O}$ or THF (30 $\mathrm{mL})$ at room temperature, was added a solution of $\mathbf{4 a}(0.42 \mathrm{~g}$; $0.85 \mathrm{mmol})$ in $\mathrm{Et}_{2} \mathrm{O}$ or THF $(20 \mathrm{~mL})$. ${ }^{1} \mathrm{H} \mathrm{NMR}$ in $\mathrm{C}_{6} \mathrm{D}_{6}$ showed this powder to be a 1:1 mixture of $\mathbf{1 a}$ and $\mathbf{4 a}$.

Method B: With Potassium Metal. To a stirred solution of $\mathbf{l a}$ in THF (30 mL), prepared in situ from t-BuNCHCHNt-Bu (1.25 g; $7.43 \mathrm{mmol}$ ) and $\mathrm{ZnMe}_{2}(7.5 \mathrm{~mL}$ of a $1.0 \mathrm{M}$ solution in pentane, $7.5 \mathrm{mmol})$, was added finely divided potassium $(0.29 \mathrm{~g} ; 7.42 \mathrm{mmol})$ in THF $(20 \mathrm{~mL})$ at room temperature. After the mixture was stirred for $16 \mathrm{~h}$, the solvent was removed in vacuo, leaving an orange-brown residue. The residue was washed with hexanes or $\mathrm{Et}_{2} \mathrm{O}(50 \mathrm{~mL})$ and dried in vacuo, giving 9a as a yellow-brown powder, yield $2.09 \mathrm{~g}(7.26 \mathrm{mmol}$; 98\%). ${ }^{1} \mathrm{H}$ NMR (THF- $\left.-\mathrm{d}_{8}\right): \delta 5.65(\mathrm{~s}, 2, \mathrm{NCH}=) ; 1.16(\mathrm{~s}, 18$, $\left.\mathrm{C}\left(\mathrm{CH}_{3}\right)_{3}\right) ;-0.82\left(\mathrm{~s}, 3, \mathrm{CH}_{3}\right) .{ }^{13} \mathrm{C} \mathrm{NMR}\left(\mathrm{THF}-\mathrm{d}_{8}\right): \delta 114.4$

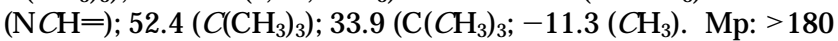
${ }^{\circ} \mathrm{C}$. Anal. Calcd for $\mathrm{C}_{11} \mathrm{H}_{23} \mathrm{KN}_{2} \mathrm{Zn}$ : C, 45.91; $\mathrm{H}, 8.06 ; \mathrm{N}, 9.73$. Found: C, 46.08; $\mathrm{H}, 8.01 ; \mathrm{N}, 9.64$.

General Procedure for the Addition of $\mathrm{K}(\mathrm{t}-\mathrm{BuNCH}-$ CHN-t-Bu) to $\mathbf{Z n R} \mathbf{R}_{2}$. To a stirred solution of $t-B u N C H C H N-$ t-Bu in THF (50 mL) was added 1 equiv of finely divided potassium at room temperature. After the mixture was stirred for $16 \mathrm{~h}$, an equimolar amount of $\mathrm{ZnR}_{2}$ was added to the brown suspension. The resulting clear solution was stirred for an additional $30 \mathrm{~min}$. The solvent was removed in vacuo, leaving an orange-brown sticky residue. The residue was washed with $\mathrm{Et}_{2} \mathrm{O}(50 \mathrm{~mL})$ and dried in vacuo.

(a) To ZnMe. The reaction of t-BuNCHCHN-t-Bu (1.12 g; $6.7 \mathrm{mmol}$ ), potassium (0.26 g; $6.7 \mathrm{mmol})$, and $\mathrm{ZnMe}_{2}(6.7$ $\mathrm{mL}$ of a $1.0 \mathrm{M}$ solution in pentane, $6.7 \mathrm{mmol}$ ) gave the product as a yellow-brown powder, isolated yield $1.78 \mathrm{~g}(6.19 \mathrm{mmol}$; $93 \%$ ). ${ }^{1} \mathrm{H}$ and ${ }^{13} \mathrm{C}$ NMR (videsupra) showed this powder to be pure 9 a.

(b) To ZnEt 2 . The reaction of t-BuNCHCHN-t-Bu (1.33 g; $7.93 \mathrm{mmol}$ ), potassium $(0.31 \mathrm{~g} ; 7.90 \mathrm{mmol})$, and $\mathrm{ZnEt}_{2}(8.0 \mathrm{~mL}$ of a $1.0 \mathrm{M}$ solution in hexane, $8.0 \mathrm{mmol}$ ) gave the product as a yellow-brown powder, isolated yield $1.84 \mathrm{~g}$. ${ }^{1} \mathrm{H}$ and ${ }^{13} \mathrm{C} N \mathrm{NR}$ showed this powder to be a mixture of $\mathbf{9 b}(57 \%)$ and $\mathbf{1 0 b}(43 \%)$. I dentical reaction at $0.15 \mathrm{M}$ t-BuNCHCHN-t-Bu concentration and $195 \mathrm{~K}$ yielded a mixture of $\mathbf{9 b}(73 \%)$ and $\mathbf{1 0 b}(27 \%)$. I dentical reaction at $0.03 \mathrm{M}$ t-BuNCHCHN-t-Bu concentration and $298 \mathrm{~K}$ gave a mixture of $\mathbf{9 b}(77 \%)$ and $\mathbf{1 0 b}(23 \%)$. We have been unable to separate the two products. 9b: ${ }^{1} \mathrm{H}$ NMR $\left(\mathrm{THF}-\mathrm{d}_{8}\right) \delta 5.62(\mathrm{~s}, 2, \mathrm{NCH}=), 1.21\left(\mathrm{t}, 3, \mathrm{CH}_{3}\right), 1.16(\mathrm{~s}, 18$, $\left.\mathrm{C}\left(\mathrm{CH}_{3}\right)_{3}\right), 0.10\left(\mathrm{q} \mathrm{br}, 2, \mathrm{CH}_{2}\right) ;{ }^{13} \mathrm{C} \mathrm{NMR}\left(\mathrm{THF}-\mathrm{d}_{8}\right) \delta 114.3$ $(\mathrm{NCH}=), 52.1\left(\mathrm{C}\left(\mathrm{CH}_{3}\right)_{3}\right), 33.9\left(\mathrm{C}\left(\mathrm{CH}_{3}\right)_{3}\right), 14.7\left(\mathrm{CH}_{3}\right), 3.6\left(\mathrm{CH}_{2}\right)$; $\mathrm{mp}>180{ }^{\circ} \mathrm{C}$. 10b: ${ }^{1} \mathrm{H}$ NMR $\left(\mathrm{THF}-\mathrm{d}_{8}\right) \delta 5.45(\mathrm{~s}, 1, \mathrm{NCH}=)$, $2.45\left(\mathrm{q}, 2,{ }^{3} \mathrm{~J}=7.2 \mathrm{~Hz}, \mathrm{NC}\left(\mathrm{CH}_{2}\right)=\right), 1.29\left(\mathrm{~s}, 9, \mathrm{C}\left(\mathrm{CH}_{3}\right)_{3}, 1.14\right.$ $\left(\mathrm{s}, 9, \mathrm{C}\left(\mathrm{CH}_{3}\right)_{3}\right), 1.21\left(\mathrm{t}, 3, \mathrm{CH}_{3}\right), 0.10\left(\mathrm{q} \mathrm{br}, 2, \mathrm{CH}_{2}\right) ;{ }^{13} \mathrm{C} \mathrm{NMR}$ $\left(\mathrm{THF}-\mathrm{d}_{8}\right) \delta 126.6\left(\mathrm{NC}\left(\mathrm{CH}_{2}\right)=\right), 114.9(\mathrm{NCH}=), 53.0,52.2$ $\left(\mathrm{C}\left(\mathrm{CH}_{3}\right)_{3}\right), 36.6,33.9\left(\mathrm{C}\left(\mathrm{CH}_{3}\right)_{3}\right), 26.7\left(\mathrm{NC}\left(\mathrm{CH}_{2}\right)=\right), 15.8\left(\mathrm{CH}_{3}\right)$, $3.6\left(\mathrm{CH}_{2}\right)$.

(c) $\mathbf{T o} \mathbf{Z n}\left(\mathbf{C H}_{2} \mathbf{P h}\right)_{2}$. The reaction from t-BuNCHCHN-t$\mathrm{Bu}$ (1.89 g; $11.23 \mathrm{mmol}$ ), potassium (0.44 g; $11.25 \mathrm{mmol}$ ), and $\mathrm{Zn}\left(\mathrm{CH}_{2} \mathrm{Ph}\right)_{2}(2.74 \mathrm{~g} ; 11.06 \mathrm{mmol})$ gave the product as an orange powder, yield $4.35 \mathrm{~g}$. ${ }^{1} \mathrm{H}$ and ${ }^{13} \mathrm{C}$ NMR showed this powder to be a mixture of $\mathbf{9 c}(\mathbf{7 0} \%)$ and $\mathbf{1 0 c}(30 \%)$. We have been unable to separate the two products. 9c: ${ }^{1} \mathrm{H} \mathrm{NMR}\left(\mathrm{THF}-\mathrm{d}_{8}\right) \delta 6.9-$ $6.8(\mathrm{~m}, 4 \mathrm{H}, \mathrm{ArH}), 8.52$ (dd, 1H, ArH), 5.60 (s, 2, NCH=), 1.88 (s br, 2, $\left.\mathrm{CH}_{2}\right), 1.15\left(\mathrm{~s}, 18, \mathrm{C}\left(\mathrm{CH}_{3}\right)_{3}\right) ;{ }^{13} \mathrm{C} \mathrm{NMR}\left(\mathrm{THF}-\mathrm{d}_{8}\right) \delta 153.9$ $\left(\mathrm{Ar} \mathrm{C}_{\text {ipso }}\right), 128.1,127.0,119.4(\mathrm{ArC}), 114.1(\mathrm{NCH}=), 52.2$ $\left(\mathrm{C}\left(\mathrm{CH}_{3}\right)_{3}\right), 33.9\left(\mathrm{C}\left(\mathrm{CH}_{3}\right)_{3}\right), 23.2\left(\mathrm{CH}_{2}\right) .10 \mathrm{c}:{ }^{1} \mathrm{H}$ NMR $\left(\mathrm{THF}-\mathrm{d}_{8}\right)$ $\delta$ 7.4-6.4 (aryl), $5.61(\mathrm{~s}, 1, \mathrm{NCH}=), 3.71\left(\mathrm{~s}, 2, \mathrm{NC}\left(\mathrm{CH}_{2}\right)=\right), 1.89$ (s br, 2, $\left.\mathrm{CH}_{2}\right), 1.23$ (s, 9, $\left.\mathrm{C}\left(\mathrm{CH}_{3}\right)_{3}\right), 1.09\left(\mathrm{~s}, 9, \mathrm{C}\left(\mathrm{CH}_{3}\right)_{3}\right.$.

Preparation of $\left[\mathrm{Zn}\left(\mathrm{CH}_{2} \mathrm{Ph}\right)(\mathrm{t}-\mathrm{BuNCHCHN}-\mathrm{t}-\mathrm{Bu})\right]_{2}(\mathbf{4 c})$. Compl ex $\mathbf{4 c}$ was prepared according to a literature procedure, ${ }^{3}$ with a slightly modified workup, starting from t-BuNCHCHN- 
Table 4. Crystal Data and Details of the Structure Determination for $\left\{9 a(T H F)_{n}\right.$ and $\left\{9 c\left(E t_{2} O\right)_{1 / 2}\right\}_{n}$

\begin{tabular}{|c|c|c|}
\hline & $\{9 a(\text { THF })\}_{\mathbf{n}}$ & $\left\{9 c\left(E t_{2} O\right)_{1 / 2}\right\}_{n}$ \\
\hline $\begin{array}{l}\text { empirical formula } \\
\text { mol wt } \\
\text { cryst syst } \\
\text { space group } \\
\text { a, } \AA \\
\text { b, } \AA \\
c, \AA \\
V, \AA^{3} \\
Z \\
D_{\text {calcd }} \mathrm{g} \mathrm{cm}^{-3} \\
\mu(\text { Mo K } \alpha), \mathrm{cm}^{-1} \\
\text { cryst size, } \mathrm{mm}^{-}\end{array}$ & \begin{tabular}{l}
\multicolumn{1}{c}{ Crystal Data } \\
$\mathrm{C}_{15} \mathrm{H}_{31} \mathrm{KN} \mathrm{N}_{2} \mathrm{OZn}$ \\
359.91 \\
orthorhombic \\
Pnma (No. 62) \\
$15.6658(7)$ \\
$21.5705(11)$ \\
$11.3578(9)$ \\
$3838.0(4)$ \\
8 \\
1.246 \\
15.0 \\
$0.13 \times 0.38 \times 0.50$
\end{tabular} & $\begin{array}{l}\mathrm{C}_{19} \mathrm{H}_{32} \mathrm{KN}_{2} \mathrm{O}_{1 / 2} \mathrm{Zn} \\
400.96 \\
\text { orthorhombic } \\
\mathrm{P} 21212(\mathrm{No} .18) \\
18.712(2) \\
10.634(2) \\
10.803(8) \\
2149.6(17) \\
4 \\
1.239 \\
13.4 \\
0.08 \times 0.38 \times 0.38\end{array}$ \\
\hline $\begin{array}{l}\text { temp } K \\
\text { radiation; } \lambda, \AA \\
\theta_{\min }, \theta_{\max }, \text { deg } \\
\text { sca type } \\
\text { data set } \\
\text { total no. of data } \\
\text { total no. of unique data }\end{array}$ & $\begin{array}{l}150 \quad \text { Data Collection } \\
\text { Mo K } \alpha \text { (graphite); } 0.71073 \\
1.9,27.5 \\
\omega / 2 \theta \\
-16 \text { to }+20,0 \text { to }+27,-14 \text { to } 0 \\
6685 \\
4526\end{array}$ & $\begin{array}{l}150 \\
\text { Mo K } \alpha \text { (graphite); } 0.71073 \\
1.9,25 \\
\omega / 2 \theta \\
-21 \text { to }+24,0 \text { to }+3,0 \text { to }+14 \\
3897 \\
3421\end{array}$ \\
\hline $\begin{array}{l}\text { no. of refined params } \\
R 1, \text { wR2, Sa }\end{array}$ & $\begin{array}{l}280 \quad \text { Refinement } \\
0.0495,0.1151,1.02\end{array}$ & $\begin{array}{l}221 \\
0.0976,0.248,1.14\end{array}$ \\
\hline
\end{tabular}

t-Bu (1.42 g; $8.44 \mathrm{mmol}$ ), potassium (0.33 g; $8.44 \mathrm{mmol}$ ), and $\mathrm{Zn}\left(\mathrm{CH}_{2} \mathrm{Ph}\right) \mathrm{Cl}$, prepared in situ from $\mathrm{Zn}\left(\mathrm{CH}_{2} \mathrm{Ph}\right)_{2}(1.05 \mathrm{~g} ; 4.24$ $\mathrm{mmol})$ and $\mathrm{ZnCl}_{2}\left(7.0 \mathrm{~mL}\right.$ of a $0.62 \mathrm{M}$ solution in $\mathrm{Et}_{2} \mathrm{O}, 4.34$ $\mathrm{mmol})$. Extraction of the product mixture with $\mathrm{CH}_{2} \mathrm{Cl}_{2}(2 \times$ $50 \mathrm{~mL}$ ) gave $4 \mathrm{c}$ as a yellow powder in $2.15 \mathrm{~g}$ (3.31 mmol; 78\%) yield. ${ }^{1} \mathrm{H}$ NMR $\left(\mathrm{C}_{6} \mathrm{D}_{6}\right): \delta 7.45(\mathrm{~d}, 3 \mathrm{H}, \mathrm{N}=\mathrm{CH}$ and $\mathrm{Ar} \mathrm{H}), 7.39$ (dd, $2 \mathrm{H}, \mathrm{Ar} \mathrm{H}), 6.96$ (dd, $1 \mathrm{H}, \mathrm{Ar} \mathrm{H}), 2.58$ (d, $1 \mathrm{H}, \mathrm{NCH}), 2.45$ $\left(\mathrm{dd}, 2 \times 1 \mathrm{H},{ }^{2} \mathrm{~J}=10.8, \operatorname{Ar} \mathrm{CH}_{2}\right), 0.94\left(\mathrm{~s}, 9 \mathrm{H}, \mathrm{C}\left(\mathrm{CH}_{3}\right)_{3}\right), 0.90$ $\left(\mathrm{s}, 9 \mathrm{H}, \mathrm{C}\left(\mathrm{CH}_{3}\right)_{3}\right)$. ${ }^{1} \mathrm{H} \mathrm{NMR}\left(\mathrm{CD}_{2} \mathrm{Cl}_{2}\right): \delta 8.15(\mathrm{~d}, 1 \mathrm{H}, \mathrm{N}=\mathrm{CH})$, 7.2-6.7 (m, 5 H, Ar H), $3.14(\mathrm{~d}, 1 \mathrm{H}, \mathrm{NCH}), 2.00(\mathrm{dd}, 2 \times 1 \mathrm{H}$, 2 $\left.\mathrm{J}=14.9, \mathrm{ArCH} \mathrm{CH}_{2}\right), 1.16\left(\mathrm{~s}, 9 \mathrm{H}, \mathrm{C}\left(\mathrm{CH}_{3}\right)_{3}\right), 0.84\left(\mathrm{~s}, 9 \mathrm{H}, \mathrm{C}\left(\mathrm{CH}_{3}\right)_{3}\right)$. ${ }^{13} \mathrm{C}$ NMR $\left(\mathrm{CD}_{2} \mathrm{Cl}_{2}\right): \delta 171.3(\mathrm{~N}=\mathrm{CH}) ; 152.6$ (quaternary $\left.\mathrm{Ar}\right)$;

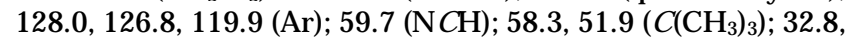
$29.6\left(\mathrm{C}\left(\mathrm{CH}_{3}\right)_{3}\right) ; 22.1\left(\mathrm{ZnCH}_{2}\right)$.

Preparation of K[ZnMe(t-BuNCHCHN-t-Bu)] (9a). To a solution of $\mathbf{4 a}(2.38 \mathrm{~g} ; 4.8 \mathrm{mmol})$ in THF $(50 \mathrm{~mL})$ was added finely divided potassium $(0.38 \mathrm{~g} ; 9.7 \mathrm{mmol})$. After the mixture was stirred for $16 \mathrm{~h}$ at room temperature, the solvent was removed in vacuo, leaving a yellow-brown residue. The residue was washed with $\mathrm{Et}_{2} \mathrm{O}(2 \times 20 \mathrm{~mL})$ and dried in vacuo, giving 9a as a yellow powder, isol ated yield $2.73 \mathrm{~g}(9.5 \mathrm{mmol}$; 99\%). Crystals of $\{\mathbf{9 a} \text { (THF) }\}_{\mathbf{n}}$ were obtained by crystallization from a 1:5 mixture of $\mathrm{THF}$ and $\mathrm{Et}_{2} \mathrm{O}$ at $-30{ }^{\circ} \mathrm{C}$.

Preparation of K[ZnEt(t-BuNCHCHN-t-Bu)] (9b). Complex $\mathbf{9 b}$ was synthesized according to the procedure for $\mathbf{9 a}$, starting from $\mathbf{4 b}(2.72 \mathrm{~g} ; 10.35 \mathrm{mmol})$ and potassium (0.42 g; $10.74 \mathrm{mmol})$; isolated yield $2.90 \mathrm{~g}(9.61 \mathrm{mmol}$; $93 \%)$.

Preparation of $\mathrm{K}\left[\mathrm{Zn}\left(\mathrm{CH}_{2} \mathrm{Ph}\right)(\mathrm{t}-\mathrm{BuNCHCHN}-\mathrm{t}-\mathrm{Bu})\right]$ (9c). Complex 9c was synthesized according to the procedure for 9a, starting from 4c $(2.02 \mathrm{~g} ; 6.22 \mathrm{mmol})$ and potassium $(0.24$ g; $6.14 \mathrm{mmol}$ ); isolated yiel d $1.91 \mathrm{~g}(5.88 \mathrm{mmol}$; $96 \%)$. Crystals of $\left\{\mathbf{9 c}\left(\mathbf{E t}_{\mathbf{2}} \mathbf{O}\right)_{\mathbf{1} / \mathbf{2}}\right\}_{\mathbf{n}}$, suitable for an X-ray diffraction study, were obtained by crystallization from a 1:5 mixture of THF and $\mathrm{Et}_{2} \mathrm{O}$ and were not dried.

X-ray Structure Determination for $\{9 \mathrm{a}(\mathrm{THF})\}_{\mathbf{n}}$ and $\left\{\mathbf{9 c}\left(\mathbf{E t}_{\mathbf{2}} \mathbf{O}\right)_{1 / 2}\right\}_{\mathbf{n}}$. X-ray data were collected on an Enraf-N oniusCAD4T diffractometer on a rotating anode for transparent, cut to size, inert-oil-covered crystals that were glued on top of a glass fiber and stabilized by the cold dinitrogen stream at 150
K. Pertinent numerical data have been collected in Table 4. The best available crystals of $\left\{\mathbf{9 c}\left(\mathbf{E t}_{\mathbf{2}} \mathbf{O}\right)_{\left.\mathbf{1}_{\mathbf{2}}\right\}_{\mathbf{n}}}\right.$ were of poor quality, as indicated by broad and structured reflection profiles and signs of intergrowth. Unit cell parameters were derived from the SET $4{ }^{19}$ setting angles. The data were corrected for Lp and absorption (empirical PLATON ${ }^{20}$ ) and averaged. The structure was solved with automated Patterson techniques (DIRDIF $92^{21}$ ) and refined on $\mathrm{F}^{2}$ by full-matrix least squares (SHELXL 9322). Non-hydrogen atoms were refined with anisotropic displacement parameters. Hydrogen atoms were included at calculated positions, riding on and with isotropic displacement parameters derived from their carrier atoms. One of the $\left[\mathrm{ZnC}_{11} \mathrm{H}_{23} \mathrm{~N}_{2}\right]^{-}$anions of $\{\mathbf{9 a}(\mathbf{T H F})\}_{\mathbf{n}}$ is disordered over an inversion center. The weak data quality of $\left\{\mathbf{9 c}\left(\mathbf{E t}_{\mathbf{2}} \mathrm{O}\right)_{\mathbf{1 / 2}}\right\}_{\mathbf{n}}$ is reflected in the relatively high final $\mathrm{R}$ value and some unusual displacement ellipsoids. Both structures were checked for higher symmetry and residual voids (PLATON $\left.^{20}\right)$. The Flack parameter for $\left\{\mathbf{9 c}\left(\mathbf{E t}_{\mathbf{2}} \mathbf{O}\right)_{\mathbf{1} / \mathbf{2}}\right\}_{\mathbf{n}}$ was refined to $-0.04(6)$.

Acknowledgment. This work was supported in part (E.R. and A.L.S.) by the Netherlands Foundation for Chemical Research (SON) with financial aid from the Netherlands Organization for Scientific Research (NWO).

Supporting Information Available: Further details on the structure determinations, including tables of atomic coordinates, all bond lengths and angles, and thermal parameters, for $\{\mathbf{9 a}(\mathbf{T H F})\}_{\mathbf{n}}$ and $\left\{\mathbf{9 c}\left(\mathbf{E t}_{\mathbf{2}} \mathbf{O}\right)_{\mathbf{1 / 2}}\right\}_{\mathbf{n}}$ (24 pages). Ordering information is given on any current masthead page.

\section{OM 9701480}

(19) Boer, J . L.; Duisenberg, A. J . M. Acta Crystallogr. 1984, A40, C410.

(20) Spek, A. L. Acta Crystallogr. 1990, A46, C34.

(21) Beurskens, P. T.; Admiraal, G.; Beurskens, G.; Bosman, W. P.; Garcia-Granda, S.; Gould, R. O.; Smits, J. M. M.; Smykalla, C. The DIRDIF Program System; Technical Report of the Crystallography Laboratory; University of Nijmegen, Nijmegen, The Netherlands, 1992.

(22) Sheldrick, G. M. SHELXL-93 Program for Crystal Structure Refinement; University of Göttingen, Göttingen, Germany, 1993. 